\title{
TRAINING AVIATORS OF THE HIGHEST QUALIFICATION IN INDEPENDENT LITHUANIA (1990-2009)
}

\author{
Algimantas Liekis \\ Vilnius Gediminas Technical University \\ Saulètekio al. 11, LT-10223 Vilnius, Lithuania \\ E-mail:liekis@adm.vgtu.lt
}

Received 18 March 2009, accepted 10 April 2009

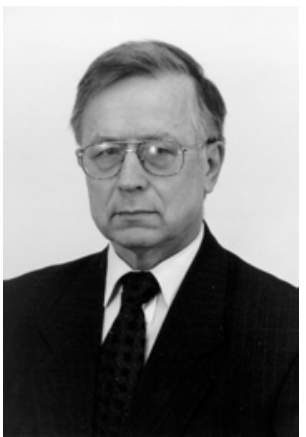

\begin{abstract}
Algimantas LIEKIS, Assoc Prof Dr
Date and place of birth: Oct.16, 1943 in Stokaičiai Village, Tauragè Distr. Lithuania

Education: 1966 - civil engneer, Kaunas Politech. Instit. (now - Kaunas University of Technology), Department of Civil Engineering.

Affiliations and functions: Doctor of Humanities (History), Associate Professor. Editor-in-Chief of the journals Science of Lithuania ("Lietuvos mokslas") and Lithuanian Nation ("Lietuviu tauta")".

Research interests: history of Technical science.

Publications: author of 34 monographs and compiler of 60 collective books of monograph type.

Present position: director of the Science Research Centre at Vilnius Gediminas Technical University.
\end{abstract}

\begin{abstract}
The goal of this article is to generalize the analysis carried out by the author of how the preparation of the highest quality aviation specialists was organized after Lithuania re-established its independence in 1990. It deals with the impact of the then existing system of higher and special studies, the system of education, the operating and newly established civil, military and sports aviation organizations, aviation technology, and other enterprises. The article will serve to further solve the issues relating to the preparation of aviators and other specialists of the highest qualification.
\end{abstract}

Key words: training of aviators, Aviation Institute, aviation companies, study model, Aeronautics Technology Platform.

\section{Introduction}

In Lithuania since olden times there have been people who were ambitious to soar like birds. Already in 1650, in Amsterdam, the Lithuanian military engineer Kazimieras Simenavičius published the book The Great Art of Artillery, giving a description of multi-stage rockets and opportunities for their application. Three centuries later, K. Tsiolkovsky, the Russian scientist and the propagator of the idea of flights to other planets, as well as the creators of spaceships used to study this work.

Flights became an object of special interest after WWI, after Lithuania gained its independence. At the beginning of 1919, an aviation subdivision was formed in the Lithuanian Army, and on March 12 a military aviation school was set up, even though there were neither teachers nor training facilities. The students practised during their flights against the Red Army of Bolshevist Russia that invaded the country and against Polish Bermont troops (Liekis 2007). Some students with a higher education also acted as teachers. At the end of 1919, 34 Lithuanians, aerial reconnaissance pilots, graduated from the school (Liekis 1999). To maintain such a school in those years was a very difficult task, and it was therefore decided to train the aviators in the army, establishing for that purpose a special training aerial squadron and organizing acrobatic flying courses. With the advancement of technical progress, however, such training of aviators did not satisfy the needs of that time. Beginning in 1932, the preparation of aviators was therefore started again in the re-established military aviation school, which functioned until the Soviet 
occupation in the summer of 1940 (Liekis 2002).

Even though military aviation in Lithuania was started from nothing after acquiring several damaged aircraft dating from WWI, by 1936 it already possessed distant and close reconnaissance, communications, fighter planes, and bomber squadrons. But most importantly, the majority of aircraft were created by the Lithuanian designers and manufactured in military aviation workshops (mostly ANBO-type aircraft designed by Antanas Gustaitis). According to their technical qualities, they were on a par with those produced in the developed industrial countries. One more thing that Lithuania could be proud of was the flights of pilots, including the flight of Steponas Darius and Stasys Girenas in 1933 across the Atlantic by a single-engine aircraft, which was the fourth flight as to distance and time The flights by three ANBOIV aircraft around Europe in the spring of 1937 astounded the Western countries (the aircraft crews consisted of A. Gustaitis and J. Namikas, J. Liorentas and R. Marcinkus, and J. Mikènas and K. Rimkevičius).

For aviation to achieve a mass character, of importance was the establishment of the Lithuanian Aeroclub in 1927, which all the time was supported by the military aviation. With the efforts of the Aeroclub, in many places of Lithuania groups of glider pilots, their builders, model aircraft constructors, parachutists, and air scouts started functioning. Soon the name of Lithuania was famed due to the enthusiasts of aircraft sports of the Aeroclub. In Nida, a gliding school was founded with the efforts of the enthusiasts, and its students, flying with gliders of their own design and manufacture, improved several records in this field. In 1937, the glider pilot and aircraft designer B. Ožkinis and glider pilot Jonas Pyragius participated in the Eighth Gliding Contest (with gliders constructed by B. Ožkinis) in the U.S.A. (Elmira).

In the First Baltic Aviation Sports Competition, held on August 13-19, 1939, the Lithuanian aviators were winners in almost all the fields. Both in military and sports aviation, only the flying machines of Lithuanian design and construction prevailed.

The Lithuanian Union of Riflemen, one of the major organizations in Lithuania, had their own aviation unit. In 1938, passenger aircraft began flying between Kaunas and Palanga and somewhat later also between Kaunas and Riga.

In pre-war independent Lithuania, aviation was a prestigious field and favoured by young people. It contributed greatly to the development of engineering studies and research work in Lithuania.

In the summer of 1940, after the Soviet Union occupied Lithuania and other Baltic States, a number of military aviation specialists were arrested, deported and killed; most aircraft were incorporated into the $29^{\text {th }}$ Special Baltic Corps of the occupying Red Army. Only a small number of aviators managed to retreat to the West. The gliders were allowed to fly only in Aukštagiris near Vilnius. In the early spring of 1941, the aviation designer and former commander of Lithuanian military aviation, Antanas Gustaitis, was deported to Moscow, where he was shot on October 16, 1941. After the German occupation, in Kaunas only diving enthusiasts managed to start their flights again from the slopes of Kulautuva, in most cases in gliders of their own make. The occupational authorities permitted several gliders to be brought from Aukštagiris (Liekis 2008).

After the repeated occupation of Lithuania by the Soviet Union, the first to revive the manufacture of gliders and flights were the students of Vytautas Magnus University in Kaunas. The studies of glider pilots and parachutists were under the strict control of the occupational authorities, however. In 1947, in Vilnius and Kaunas, aviation sports and technical clubs under Russian reservist military men, airborne soldiers, were established by the USSR OSOAVIACHIM (USSR Union for Support of Defence, Aviation and Chemical Industry) subunit in Lithuania. The goal of the clubs was to prepare young people for the Soviet Army. It was planned to prepare glider pilots and parachutists in Kaunas and sports pilots and parachutists in Vilnius. However, fearing that the pilots might fly to the West, the occupants forbade aircraft sports, and this lasted almost to 1960. Thus gliding, parachuting, and aircraft designing were developed. Aviation clubs were also established in other cities and districts, like Panevėžys, Šiauliai, Šilutè, etc., as clubs under the subordination of the Lithuanian unit of the USSR SDAALR (the Voluntary Union for Support of Army and Aviation). It was fully supported by state funds.

Despite the restrictions and persecution through the years of occupation, Lithuanian aviators rushed to the heights. In 1953, at Kyviškès Aerodrome the first gliding competition was organized in occupied Lithuania, followed soon by a parachutist competition. In 1960, Lithuanian glider pilots and parachutists started participating in the USSR championships, where they set more than one record. In 1960, the revival of aircraft sport and acrobatic flying began mostly in the Kyviškès and later in the Paluknis Aerodrome near Vilnius. In 1983, the Vilnius aviation club organized the first competition of acrobatic flying of the socialist countries in Lithuania, and pilots from the USSR, Czechoslovakia, Poland, Rumania, Hungary, and Bulgaria participated. The Lithuanian pilots were among the best at this championship. They were also the winners of the USSR championships.

Enthusiasts, as in previous years, created and produced new gliders. However, from 1960, instead of wooden and metal gliders, flying machines from stronger and lighter materials-glass-fibre plastics-started to be created and manufactured. The initiative of a group of the Lithuanian glider pilots to design and manufacture flying machines from such materials was supported by Gen. J. Žiburkus, the chairman of the SDAALR Republican Committee. At the initiative of the engineer V. Pakarskas, the Master of Sports in Aviation, an enterprise for designing and manufacturing gliders from glass-fibre plastics - the Experimental Sports Aviation Plant (from 1995 - AB „Sportine aviacija” - was set up at a former dairy in Prienai, and in 1972 for the first time in the whole of the then Soviet Union the glider BK-7 from glass-fibre was designed and built at this plant. Afterwards many other gliders and motor gliders, equalling the best in the world by their technical qualities, were designed and manufactured. Lithuania was 
mentioned in the Soviet Union as the "sister republic" of mass aviation sports. And it is not by accident that during the years of the Soviet occupation almost all branches of aviation sport were developed quite well. Here anybody could go in for free if he/she was of good health and not under suspicion by the KGB regarding "bourgeois nationalism" or "kulak origin". The aviation clubs had to be institutions of Soviet patriotism.

However, only the individual Lithuanians succeeded in going through the complex selection process and studying in the civil or military aviation schools. Therefore, in Lithuania, which was occupied by the Soviet Union after WWII, at the Aeroflot Board of Lithuania the staff consisted of Russians, Jews, and other aliens sent from Russia. Thus, after Lithuania was proclaimed an independent state in the spring of 1990, a shortage of Lithuanian aviators was felt in the established transport air routes and military aviation.

Among the first steps of the young state was to organize the preparation of aviators. For Lithuania, which was re-establishing itself at that time, it would have been too big a burden to prepare them in the West: it would have been at least five times more expensive than in Lithuania. Even more importantly was that in the interwar independent Lithuania the idea of the establishment of a higher school of aeronautics preparing pilots, engineers, navigators, and other specialists was valued. The aircraft designer General Antanas Gustaitis put forth much effort to set up such a school. As early as 1937 he had drafted a project for such an institute. Only after Lithuania regained its independence were projects for the establishment of the aviation institution of higher education considered, however. Among the initiators was Vilnius Technical University professor Jonas Stankūnas. His ideas were supported by prof. Edmundas Kazimieras Zavadskas, rector of Vilnius Technical University, some members of the leadership of the Ministry of Communications, the leaders of Lithuanian military and civil aviation, etc. With the enormous efforts of Prof. Jonas Stankūnas and other like-minded persons, the Aviation Institute, later named the Antanas Gustaitis Aviation Institute, was founded at VTU on February 11, 1993 (Stankūnas 1998).

\section{Foundation of Antanas Gustaitis Aviation Institute}

On February 10, 1993, Prof. Jonas Stankūnas, the initiator of the foundation of the VTU Aviation Institute, was appointed its director.

Prof. Stankūnas was born in 1949 in the village of Pakenè, Rokiškis District. In 1967, he finished Kriauniai Secondary School with a silver medal, and in 1970 he graduated with honours from Krivoy Rog Civil Aviation School. In 1976, he graduated with honours from the Faculty of Automation of the Vilnius Civil Engineering Institute (now Gediminas Technical University), and in 1981 he graduated from the VISI Day Radio Apparatus Technological Postgraduate Department and defended his thesis for a candidate of technical sciences (in 1993, this was recognized as a doctoral degree), entitled "Investi- gation of Symmetrical Delay Deflection Systems for Precision Wide-Band Oscillographs". In 1995, he defended post-doctoral work in technical science (trend of electronics) "Electronic Systems for Research and Registration of Electromagnetic and Mechanical Phenomena". He was on placement in the field of aviation digital systems at the Malmö Flight Control Academy in Sweden in 1994 and at the London CITY University and the Royal Aeronautics Association in the field of aircraft computer systems in 1995. In 1997, he participated in courses for organizers of aviation studies at the headquarters of the International Civil Aviation Organization in Montreal and Cornwall Navigation Training Institute (TRAINAIR) in Canada.

Prof. Stankūnas served as an aircraft technician for the Vilnius Joint Aviation Squad in 1970-1972, master at the Radio Apparatus Technology Department in 19721975, the chief engineer of the VISI scientific research sector in 1975-1978, and the manager of the VISI scientific laboratory of delay and deflection systems in 1982-1987. He was awarded the title of chief research associate in 1984, and in 1988-1993 he served as associate professor of the VISI and KPI Radio Apparatus Department (1990). Since 1993 Prof. Stankūnas has been the director of the VGTU Antanas Gustaitis Aviation Institute and a member of the VGTU Rectorate, and since 1996 he has been a member of the VGTU Council. In 1996, he was awarded the title of professor. In 19982000 he chaired the VGTU Transport Research Institute Council. He has served as director of the Defence Technologies Centre since 2002, a representative of Lithuania on the Aeronautics and Space Committee of the EU programme Integration of European Space Research since 2003, a member of the Aeronautics Committee since 2005, a member of the Transport (which includes Aeronautics) Committee since 2007, and a member of the consultative council of EU Aeronautics Research since 2005. With the efforts of Prof. Stankūnas, the Lithuanian National Aeronautics Technology Platform (LNATP) was established in 2005, and he was elected chairman and later deputy chairman of its council.

In 1976, he was awarded a medal for the students' best research work by the USSR Ministry of Higher and Special Secondary Education and a prize from the A.S. Popov Learned Society for the work "Development and Application of the Symmetrizing Transformer". In 1997, he became a winner of the Lithuanian science prize for his cycle of collected works "Wide-band Electronic Devices for Information Processing Systems" (19811996). In 2000, he was awarded a Darius and Girènas medal for merits in developing and strengthening the protection of the Republic of Lithuania, and in 2005 he was awarded the Order of St. Stanislovas (Ukraine) for the achievements in the furtherance of public progress. He is a co-author of the monographs Wide-band Tracts of Oscillographic Electronic Pipes and Transport, and the author or co-author of 14 inventions, 84 research papers, 74 scientific reports, and 9 methodological training publications.

Jonas Stankūnas is a scientist of extremely broad interests, not being satisfied just with research and pedagogical activities. While working at VISI and KPI 
Radio Apparatus Technology Department, he headed the ethnographic ensemble Raskila for quite a long time and was an active participant. He has a special gift for rallying around himself the necessary people and is extremely diligent. It is not by chance that in 1993 the VTU (VGTU) Rectorate entrusted him with establishment of a totally new VTU subunit - the Aviation Institute. And he coped perfectly with that task. With the maximum efforts of prof. Stankūnas, the institute under his guidance grew rapidly and expanded in all directions.
With the efforts of prof. Stankūnas and others, the future regulations of the VTU Aviation Institute were developed. Here it was foreseen that the founders of the institute may be Vilnius Technical University, ministries of the Republic of Lithuania and their departments, and Lithuanian and foreign scientific and production organizations. It was suggested to arrange bachelor and master studies, to conduct scientific and methodical work, etc. The management and specialists' training programme was prepared (Fig 1).

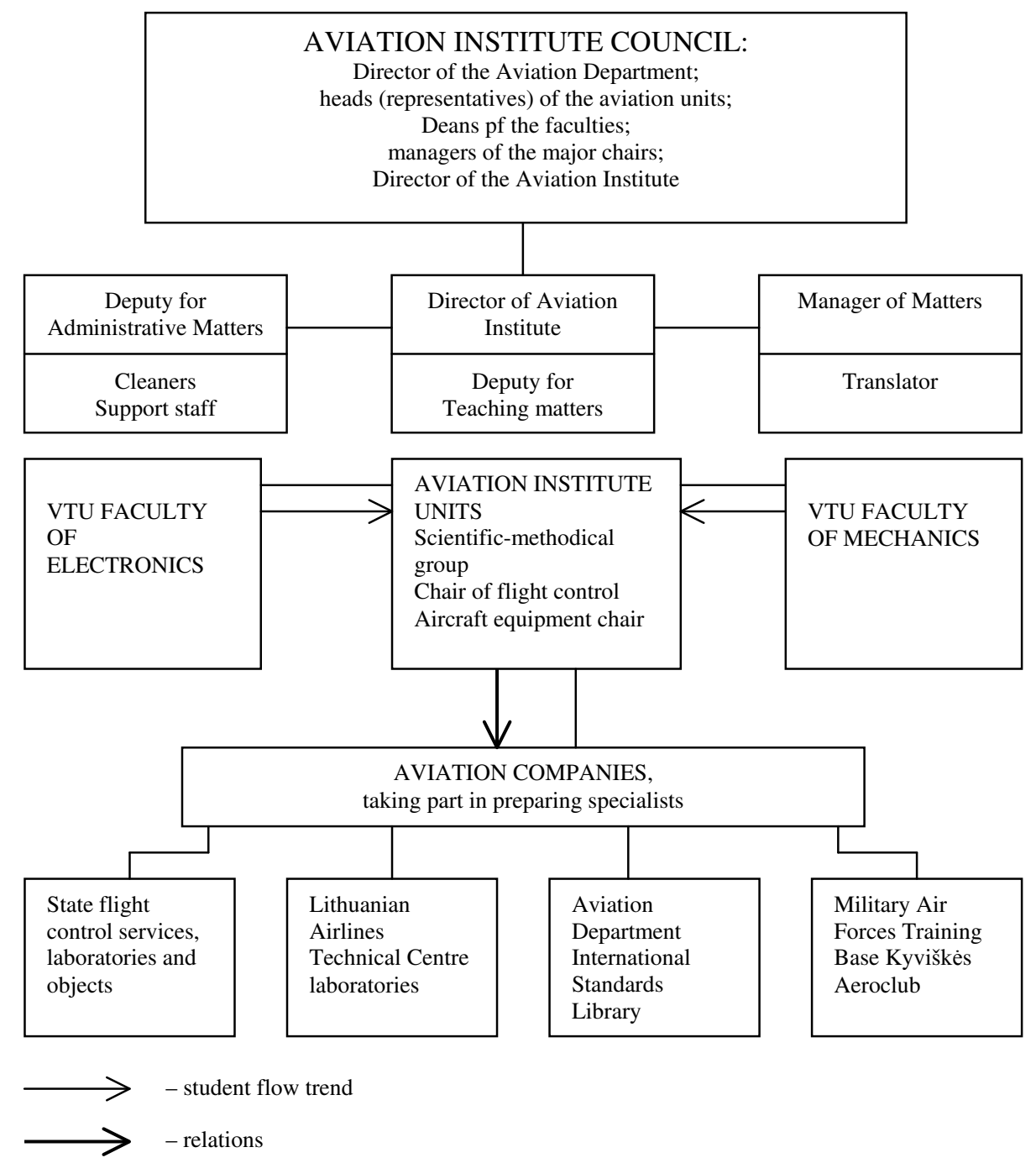

Fig 1. The Aviation Institute structural project (1992)

The goal was to prepare aviation specialists with a higher education: engineers-pilots, flight control officers, electronic engineers, electrical engineers, mechanical engineers, and air transportation managers.

Mutual obligations with the founders and sponsors were signed:

1. VTU undertakes to prepare aviation specialists with a higher education.

2. The aviation company „Lietuvos avialinijos” ("Lithuanian Airlines") transfers the training centre and other premises suitable for the teaching process to the Aviation Institute to be established under VTU and permits the technical centre laboratories and necessary facilities to be used in the teaching process.
3. The State Flight Control Service affords the use of its technical laboratories and objects in the teaching process.

4. The Aviation Department of the Ministry of Communication allows using the International Standards ICAO, ECAC, and IATA Library in the teaching process.

It was agreed that at the initial stage of the activities of the Aviation Institute some 50 staff members (about 30 teachers and 20 technical and support staff) would be needed.

The founders of the institute planned to send the future teachers to Western European countries for several months for re-qualification and qualification improvement for teaching the following subjects: air law, flight 
safety, flight physiology, flight psychology and pedagogy, aviation meteorology, flight control theory, flight control technology, aerial navigation, global navigation, aerodynamics, flight dynamics, aircraft construction, aircraft engines, aviation microprocessor systems, aviation computer systems, aircraft radio navigation systems, aircraft radiolocation systems, aircraft communication systems, aircraft electric equipment and devices, airport electric and light equipment, flight control radiolocation systems, flight control radio navigation systems, and flight control communication systems (Stankūnas 1999).
Since it was planned that the laboratories and equipment of Vilnius Airport aviation units would be used for the preparation of aviation engineers, it was decided that the institute would be set up within its territory, whereas the primary stage of flying practice would be carried out at the Kyviškès Aerodrome of the Vilnius Aeroclub and the Military Air Force Training Base near Kazlų Rūda and the final stage would be carried out at the Lithuanian Airlines training centre. Practical training of the students of flight control speciality would take place at the State Flight Control Service Base (Fig 2).

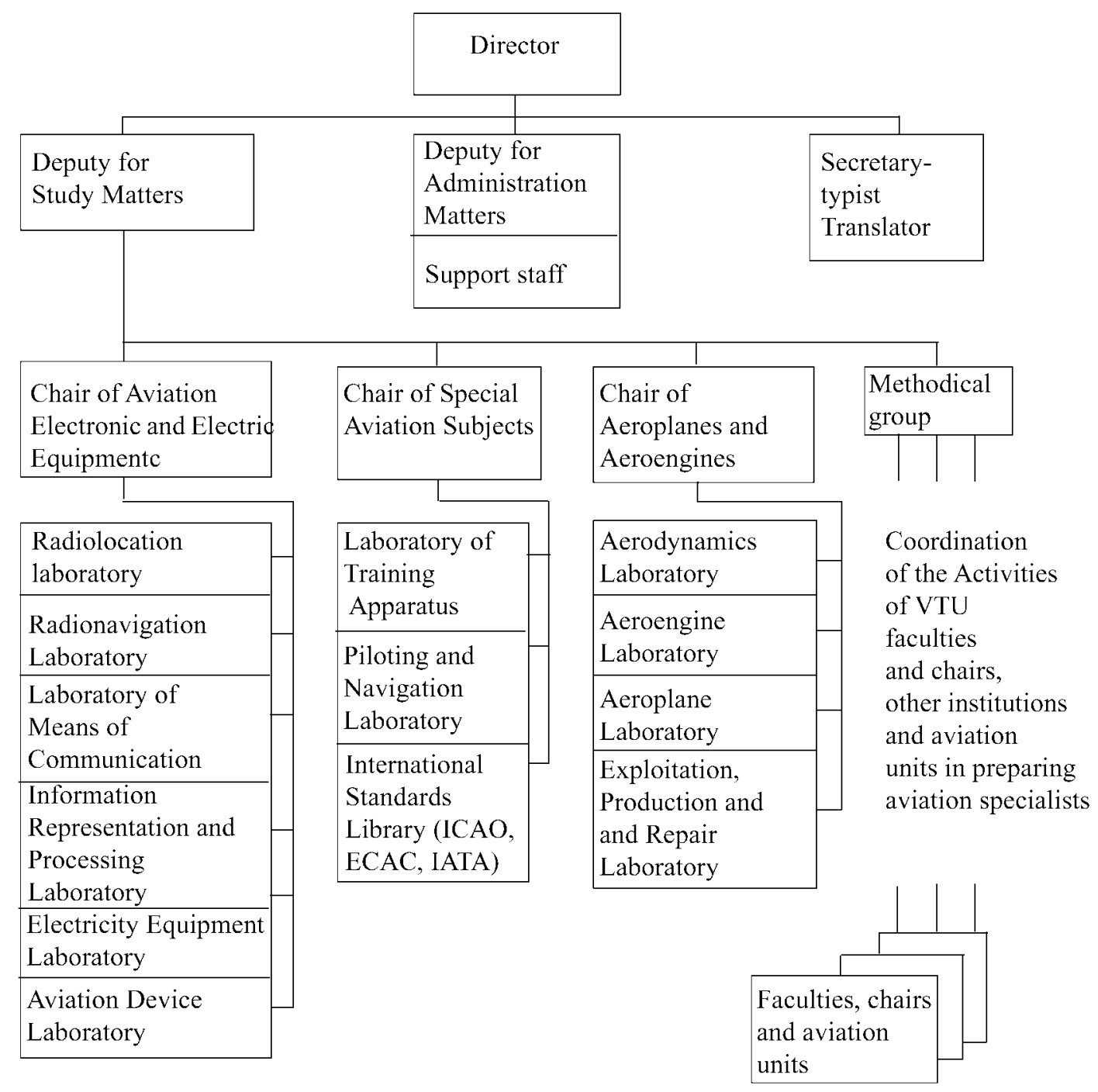

Fig 2. VTU Aviation Institute structure (1993)

The organizers of the Aviation Institute entered into relationships with foreign aviation institutes and enterprises: the Aviation and Cosmonautics Institute of the West Berlin Technical University, New York Columbia University, USA EMBRYRIDDLE Aeronautics University, BOEING in Washington, the Swedish Aviation Administration, the Malmö Flight Control Academy in Sweden, Ljungbyhed Commercial Pilot School in Sweden, Västeros Aviation College in Sweden, and other institutions (Stankūnas 1999).
The Aviation Institute was officially founded on February 11, 1993 after the rector of the university signed an order concerning its establishment and the appointment of Jonas Stankūnas as its director.

\section{Aviators and demand for them}

When setting up the institute, VGTU academics analyzed in detail the existing and possible demand for aviators in the future and its dynamics. At the beginning 
of 1993, the number of pilots in Lithuania totalled 389 (soon this number dropped to 130 since some left for Russia and others retired), 30 navigators, 192 aviation engineers, 375 aviation technicians, 70 aviation mechanics, and 107 flight control officers.

Eighty percent of Lithuanian civil aviation specialists worked in Vilnius, 14 percent worked in Kaunas, and 5.5 percent worked in Klaipeda and Palanga.

Of the aviation specialists, pilots and flight control officers are subject to "ageing" most quickly, and they need replacement. Lithuania did not have young (21-25 year old) pilots, since as was mentioned they were not trained in Lithuania. The number of pilots and flight control officers over 40 years of age drops suddenly, since that is the age limit at which human health begins worsening quite rapidly. Analysis showed that just for the Lithuanian civil aviation companies the Aviation Institute should annually prepare no less than 20 pilots for each and almost the same number of flight control officers (Table 1).

Table 1. Aviation specialists in civil aviation enterprises in 1993

\begin{tabular}{|l|l|c|c|c|c|c|c|}
\hline \multirow{2}{*}{ No. } & \multirow{2}{*}{ Name of the company } & \multicolumn{5}{|c|}{ Qualification of aviation specialists } \\
\cline { 2 - 7 } & & engineers & technicians & mechanics & pilots & $\begin{array}{l}\text { flight } \\
\text { control } \\
\text { officers }\end{array}$ & navigators \\
\hline 1. & $\begin{array}{l}\text { National flight control } \\
\text { service }\end{array}$ & 45 & 45 & & & 106 & \\
\hline 2. & $\begin{array}{l}\text { The airline „Lietuvos } \\
\text { avialinijos” }\end{array}$ & 106 & 194 & 70 & 280 & & 30 \\
\hline 3. & The airline ,Lietuva” & 16 & 52 & & 77 & & \\
\hline 4. & Vilnius Airport & 3 & 11 & & & & \\
\hline 5. & Palanga Airport & 3 & 19 & & & & \\
\hline 6. & $\begin{array}{l}\text { Klaipéda State Aviation } \\
\text { Enterprise }\end{array}$ & 6 & 16 & & & & \\
\hline 7. & Prienai Aviation Plant & 8 & 4 & & & & \\
\hline 8. & $\begin{array}{l}\text { Lithuanian aviation } \\
\text { clubs }\end{array}$ & 2 & 30 & & & & \\
\hline 9. & $\begin{array}{l}\text { Ministry of } \\
\text { Communications }\end{array}$ & 3 & 4 & & & & \\
\hline
\end{tabular}

Because of the need for specialists of the highest quality for the Military Air Force, Ministry of Internal Affairs, and other institutions, it was calculated that each year 30 pilots, 20 flight control officers, 20 managers, 18 aircraft electronic equipment engineers, 19 flight control electronic equipment engineers, 15 aircraft electric equipment and device engineers, 10 airport electric equipment engineers, and 20 aviation mechanical engineers should graduate from the Aviation Institute.

Models for the preparation of aviators. The models for the preparation of aviators are formed on the basis of the experience of the West European, US, and Lithuanian universities (Stankūnas et al. 2000). The difference is that in the study programmes, one is guided by the ICAO, IATA and other documents regulating the preparation of aviation specialists (Fig 3).

For first and second year bachelor students, in addition to the specialisations of aircraft piloting and flight control specialisations of general study and general engineering subjects, the speciality studies were planned. These are the most important subjects to be learnt before flight control practice. The bachelor studies of those two specialisations were to be completed not with the final work, as was the case for the engineering specialisations, but by taking state examinations.

In the diplomaed engineer and master studies, at the request of the Lithuanian Ministry of Defence that all aviation specialists with a higher education would have a military rank of an officer of the Republic of Lithuania, military preparation for the students in all aviation specialisations was to be conducted, so that after graduation from those studies the students would be awarded the rank of reserve officer or active service officer.

The Aviation Institution, while preparing specialists, was to share student flows with the university's Faculties of Electronics and Transport Engineering. The Faculty of Electronics was to prepare the bachelors in electric equipment and aviation electronics for the Institute of Aviation, and the Faculty of Transport Engineering was to prepare transport management bachelors (Stankūnas et al. 2002).

After graduation from bachelor studies in these faculties, the students were to come back to the Institute of Aviation for their final aviation specialization and for the bachelor's diploma of engineer, master's in engineering, or master's degree in of scientific studies (Stankūnas 1995).

The Faculties of Fundamental Sciences, Mechanics, Business Management and Environmental Engineering of the International Studies Centre of Vilnius Technical University were to participate in the process of preparing aviation specialists in the study processes of separate subjects or groups of subjects. 


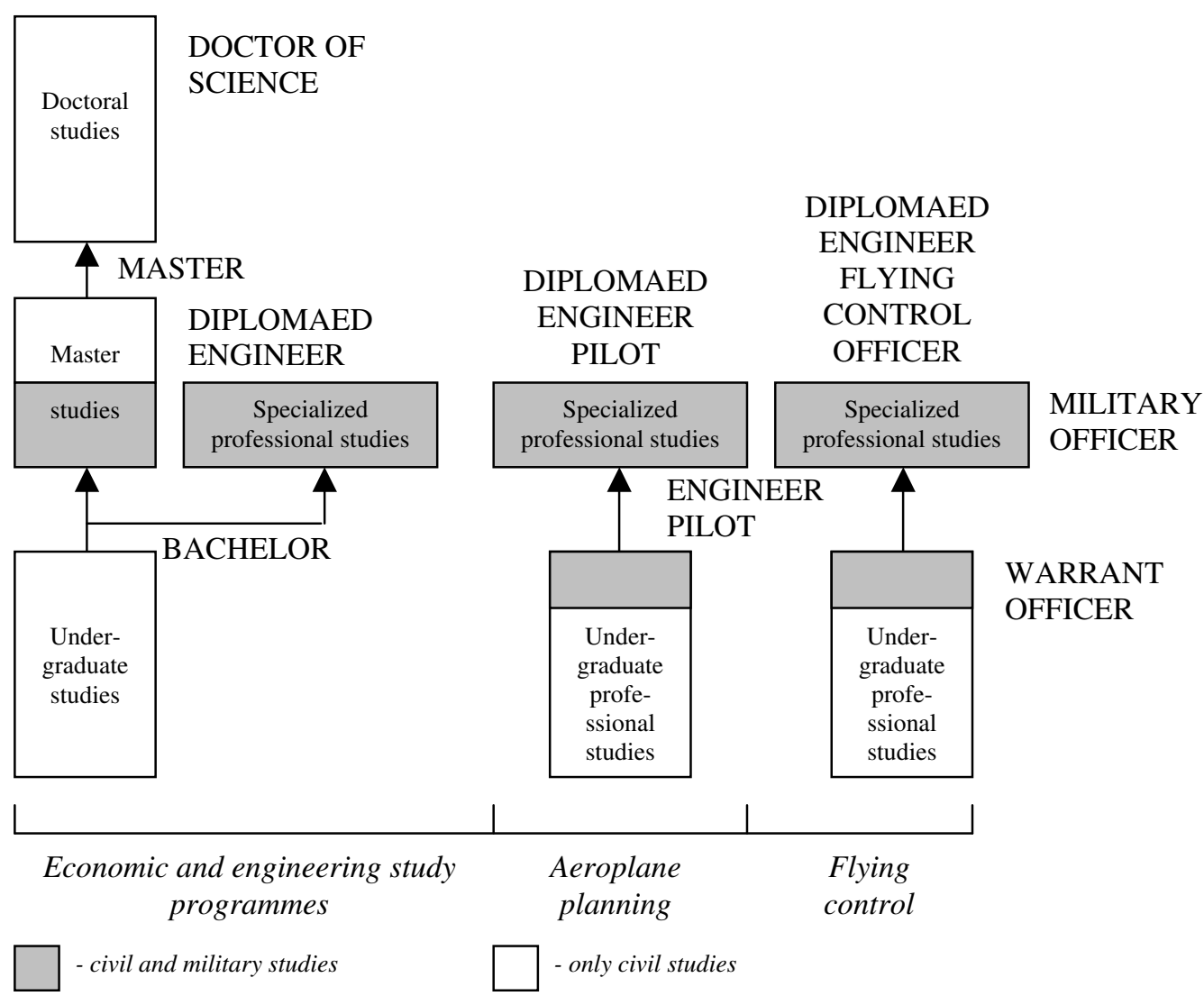

Fig 3. Study models for the training of aviation specialities

Students specialising in aircraft piloting, flight control, and aviation mechanics were to be admitted directly to the Aviation Institute. At the Aviation Institute they were also supposed to complete bachelor, diplomaed engineer, and master studies. After master studies, some of the students could undertake doctoral studies, which, if necessary, were to be organized only at the Aviation Institute or with the assistance of the VTU faculties.

The Lithuanian Military Academy and other military structures were to guide military preparation practices and organize theoretical military preparation studies.

Two levels of engineers with higher education were to be prepared at the Aviation Institute: first level private pilots (a private pilot level was to be attained after two years of studies) and second level - commercial aviation pilots (for civil aviation) and military pilots (for the Military Air Force) (this level was to be reached after the fifth year of studies) (Stankūnas 1999).

First-level flying practice was to take place with Cessna-152 and Cessna-172 trainer aeroplanes and on a computer, trainer aeroplane and aircraft An-2 trainers. Practice duration was to be 65 flying hours. In the first year of studies, after the primary theoretical preparation, 15 hours of summer flying practice at the Kyviškès Training Aerodrome with a Cessna-152 was to be organized. Parachute jumps were also planned.

In the second year of studies, 30 hours of practice were to be undertaken with a trainer aeroplane, computer, and An-2 aircraft trainers. In the second summer 20 hours of flying practice were to be carried out with Cessna-152 and Cessna-172 aeroplanes at the Kyviškès airport. After completing that practice, students were to be considered ready to obtain a private pilot's licence.

Second-level flying practice was supposed to last 85 hours. Practice with a LAK-40 trainer aircraft was to start in the third year of studies and total 20 hours. At the end of the academic year, students should be prepared for flights with an L-39 aircraft and helicopter. In the third summer, flights totalling 15 hours were to be conducted with an L-39 aircraft and helicopters at the Military Air Force Training Base at Kazlų Rūda. Here students were to finally choose a preferred type of aircraft and make a decision concerning further work.

If civil aviation is chosen, in the fourth and fifth academic year students were to carry out 50 hours of flying practice with a JAK-42 trainer aircraft. If military aviation is chosen, students were to be further prepared to pilot L-39 or other Lithuanian Military Air Force aircraft, and in the fourth and fifth academic year they were to continue practicing with JAK-40 trainer aircraft or a computer trainer, and in the fifth summer they were to fly with an L-39 jet aircraft.

If helicopter aviation is selected, they were to continue their flights with helicopters and trainers. For helicopter pilots, practice was to be somewhat shorter since 100 hours of flying is needed to receive a licence (Stankūnas 2000).

For the preparation of flight control engineers according to ICAO requirements at the Aviation Institute, flight control students have to carry out the following flight control practice: introductory, airport tower flight control approaches, flight control with and without radar, 
air space flight control without radar, and air space flight control with radar.

In the first year of studies, initial theoretical preparation, including the fundamentals of flying theory, meteorology, and aerial navigation, was to take place. In the first summer, introductory practice was to be carried out. The air space control system, electronic equipment of air navigation services, specificities of the work of a flight control officer, and sharing of work between flying control officers were all supposed to be introduced.

In the second year of studies, students were to be trained at the airport tower trainer and trainer aircraft and computer trainer at the Aviation Institute. In the second summer, tower flight control officer and short flying practice were to be carried out.

In the third year of studies, students were to be trained on the computer trainer as flying control officers for practice of flight control for approaches without and with radar to be carried out in the third summer.

In the fourth year of studies, students were to be prepared at the Aviation Institute trainer for air space control practice without and with radar to be carried out in the fourth summer and possibly continued in the fifth year of studies.

Flight control summer practice was to be conducted at the Vilnius Air Navigation Service. It was planned that flight control practice for the first group of students would be carried out in Malmö-Sturup Air Space Control Academy in Sweden or at some other educational institution of the same type, simultaneously preparing teachers and instructors for guiding those practices in Lithuania.

Seeking to minimize the costs of preparing specialists and to use qualified aviation specialists and sophisticated aviation technology in the teaching process, close contacts were to exist between the Aviation Institute, aviation enterprises, and the Military Academy.

The concrete cooperation conditions for preparing the aviation specialists were to be regulated by agreements between the Aviation Institute and aviation enterprises.

Requirements for the students who wished to enter the Aviation Institute were specified. Entrants to the aircraft piloting and flight control specialities were to be from 17 to 25 years of age, in good health and in the proper physical preparation must have successfully passed the required examinations and psychological tests. Somewhat lower requirements were planned for the "terrestrial" specialisations: aviation mechanics, management, air law, and similar specialities. For example, if the specialisation of Aircraft Piloting was selected, a student was to study informatics, engineering graphics, mathematics, physics, political science, philosophy, English, Lithuanian, theory of flights, aviation meteorology, theoretical mechanics, air communication language, aerial navigation, radiolocation, thermodynamics, aviation devices, microprocessor systems, aviation psychology, aeroengines, aircraft constructions, economics, management and some other subjects. In general, prof. Stankūnas, the Director of the Aviation Institute, together with the VTU (VGTU) professors prepared the perspective programmes of studies and science of the
Aviation Institute, which fully corresponded to the level of preparation of university studies of highest qualifycation (Stankūnas et al. 2000).

Of no less importance, however, was the fact that all calculations and actual conditions confirmed that the training of highest-quality aviators would be several times cheaper in Lithuania than in other countries (Fig 5).

\section{AGAI is the most important institution in the system preparing aviators}

VGTU Antanas Gustaitis Aviation Institute, founded thanks to the efforts of its director, Prof. Jonas Stankūnas, and other staff members, each year gained strength and became an integral part not only of the institute, but also of the entire Lithuanian higher education and aviation system.

The following study model fully justified itself:

1. Bachelor studies (4 yr.) - aircraft piloting, flight control, automation, electronics, and aviation mechanics;

2. Master studies (2 yr.) - aviation mechanics, aviation electric equipment, and aviation electronics;

3. Doctoral studies (4 yr.) - measurement engineering and transport engineering.

In addition, 1-year special professional studies (aircraft piloting and flight control) were set up.

The studies and research work are performed at the AGAI units: the Departments of Aviation Mechanics, Aviation Technologies, and Aviation Devices; the training laboratories of aviation mechanics, avionics, etc.; the training laboratory of flying trainers; bases of flight control and practice; etc. In the autumn of 2001, the Centre for Qualification Improvement of Aviation Specialists was founded in the AGAI (Fig 4).

The institute has educated many well-known scientists, academics and specialists, e.g., assoc. prof. dr. Eduardas Lazauskas, assoc. prof. dr. Kazimieras Vytautas Maceika, assoc. prof. dr. Algimantas Jakučionis, and many others. As mentioned, for preparation of AGAI specialists, other VGTU faculties, as well as Lithuanian and foreign institutions, permanently offered and offer their support:

1. VGTU faculties and units: Fundamental Sciences, Electronics, Mechanics, Business Management, Transport Engineering, Environmental Engineering, and International Studies;

2. General V. Žemaitis Lithuanian Military Academy;

3. Air companies: "Lithuanian Airlines", "Lithuanian Civil Aviation Directorate", "Vilnius International Airport", "Oro Navigacija", etc.

4. Lithuanian Military Air Force, etc. (Fig 5).

VGTU AGAI cooperates with Malmö Sturup Flight Control Academy (Sweden), Lund University (Sweden), Limerick University (Ireland), London City University (United Kingdom), Nebraska University Aviation Institute (U.S.A.), Riga Technical University (Latvia), Tartu Aviation College (Estonia), and other foreign establishments (Stankūnas et al. 2000).

The majority of relations are based on joint participation in conferences, publishing of the joint 
scientific journal Aviation, and the exchange of students and teachers.

Since 2000, VGTU AGAI has participated in UAVNET, a thematic network funded by the European Commission, and international exchange according to SOCRATES, TEMPUS, and other programmes (Stankūnas et al.1998).

Pilots at AGAI are trainingon two levels: firstprivate pilot level, achieved after 2 years of studies; second - commercial aviation (for civil aviation) and military aviation (for the Military Air Force), achieved on the fifth year of studies. First-level flying practice is carried out with aircraft Cessna-152 and Cessna -172, computers, and AN-2 trainer aircraft. Duration of practice is 50 hours of flying. After initial theoretical preparation in the first year of studies, 17 hours of summer flying practice is carried out at the training aerodrome in Kyviškès with Cessna-152 aircraft. Parachute jumps are also done.

In the second year of studies, 30 hours of training with the trainer aeroplane, computer, and An-2 aircraft trainers and 33 hours of flying practice are carried out with Cessna-152 and Cessna-172 aeroplanes at the Kyviškès Aerodrome. After completing that practice, students should be ready to obtain a private pilot's licence. Second-level flying practice lasted 90 hours. Practice starts in the third year of studies and totals 20 hours of flights with a Jak-40 trainer aircraft. At the end of the academic year, students are prepared for flights with L-39 aircraft or helicopters. In the third year, flying practice is 26 hours. In the third summer, flights totalling 15 hours are conducted with L-39 aircraft and helicopters at Military Air Force and Ministry of the Interior bases and with Cessna-15 and Cessna-172 aircraft at the Kyviškès Aerodrome and Vilnius Airport (Table 2).

Flying practice for the third and senior courses lasts the entire year.

In this period, students finally select the preferred type of aircraft and further work plans.

Having chosen civil aviation, they carry out 50 hours of flying practice with Jak-42 trainer aircraft in the fourth and fifth academic year.

If military aviation is chosen, they are further prepared to pilot L-39 aircraft or other Lithuanian Military Air Force aircraft, and further in the fourth and fifth academic year they continue practicing with TU134A trainer aircraft, and in the fourth summer they fly L-39 or L-410 aircraft.
Table 2. Facilities used at VGTU Antanas Gustaitis Aviation Institute

\begin{tabular}{|c|c|c|c|}
\hline Property & $\begin{array}{c}\text { New } \\
\text { property } \\
\text { price (of } \\
\text { analogues) }\end{array}$ & $\begin{array}{l}\text { Physica } \\
\text { l state }\end{array}$ & $\begin{array}{c}\text { Exploitation } \\
\text { expenses per } \\
\text { year, thousands } \\
\text { of LTL }\end{array}$ \\
\hline $\begin{array}{l}\text { 12-place computer flight } \\
\text { trainer, } 41 \mathrm{~m}^{2} \\
\text { (Building No. 1) }\end{array}$ & $26.000 \mathrm{LTL}$ & Good & \\
\hline $\begin{array}{l}\text { Single-engine An-2 } \\
\text { school aeroplane, } 206 \\
\mathrm{~m}^{2} \\
\text { (TVOU rented } \\
\text { premises) }\end{array}$ & $\begin{array}{l}(400.000 \\
\text { rub. } \\
\text { in 1985) }\end{array}$ & Poor & \\
\hline $\begin{array}{l}\text { Multi-engined Jak- } 40 \\
\text { school aeroplane, } 41 \mathrm{~m}^{2} \\
\text { (TVOU rented } \\
\text { premises) }\end{array}$ & $\begin{array}{l}\text { (500.000 } \\
\text { rub. } \\
\text { in 1975) }\end{array}$ & Poor & \\
\hline $\begin{array}{l}\text { Cessna-152. } 6 \text { items } \\
\text { (OL analogue) }\end{array}$ & $\begin{array}{l}25.900 \\
\text { USD } \\
\end{array}$ & $\begin{array}{l}\text { Satis- } \\
\text { factory }\end{array}$ & \\
\hline $\begin{array}{l}\text { Cessna-172. } 26 \text { items. } \\
\text { (OL analogue) }\end{array}$ & $\begin{array}{l}100.000- \\
170.000 \\
\text { USD }\end{array}$ & $\begin{array}{l}\text { Satis- } \\
\text { factory }\end{array}$ & \\
\hline $\begin{array}{l}\text { Cessna-310. } 2 \text { items. } \\
\text { (OL analogue) }\end{array}$ & $\begin{array}{l}225.000 \\
\text { USD }\end{array}$ & $\begin{array}{l}\text { Satis- } \\
\text { factory }\end{array}$ & \\
\hline $\begin{array}{l}\text { Radio communication } \\
\text { phraseological room, } 37 \\
\mathrm{~m}^{2} \\
\text { (Building No. 1) }\end{array}$ & $100.000 \mathrm{LTL}$ & Good & \\
\hline $\begin{array}{l}\text { Tower flight control } \\
\text { trainer, } 39 \mathrm{~m}^{2} \\
\text { (Building No. 1) }\end{array}$ & $50.000 \mathrm{LTL}$ & Good & $\begin{array}{l}160.0^{*}-\text { paid } \\
\text { by sponsors) }\end{array}$ \\
\hline $\begin{array}{l}\text { Flight control with and } \\
\text { without radar for } \\
\text { approaches to air space, } \\
49 \mathrm{~m}^{2} \\
\text { (Building No. 1) }\end{array}$ & $100.000 \mathrm{LTL}$ & $\begin{array}{l}\text { Satis- } \\
\text { factory }\end{array}$ & \\
\hline
\end{tabular}

After selecting helicopter aviation, students continue their flights with helicopters and trainers. For helicopter pilots, practice is somewhat shorter, since to receive a licence only 100 hours of flying is needed (Fig 5).

The most expensive area of flying practice is flights with helicopters and military aircraft.

At the Antanas Gustaitis Aviation Institute, the diplomaed engineers of flight control, prepared according to ICAO document requirements, had to carry out the following flight control practices: introduction, airport tower flight control, flight control of approaches without radar, and air space flight control with radar (Table 3).

Moreover, in the first year of studies, for flight officers themselves minimum flying practice is necessary.

In the first year of studies, initial theoretical preparation, including the fundamentals of flying theory, meteorology, and aerial navigation, all take place. In the first summer introductory practice is carried out, introducing air space control systems, electronic equipment of air navigation services, specificities of the work of the flight control officer, and sharing of work among flight control officers. 


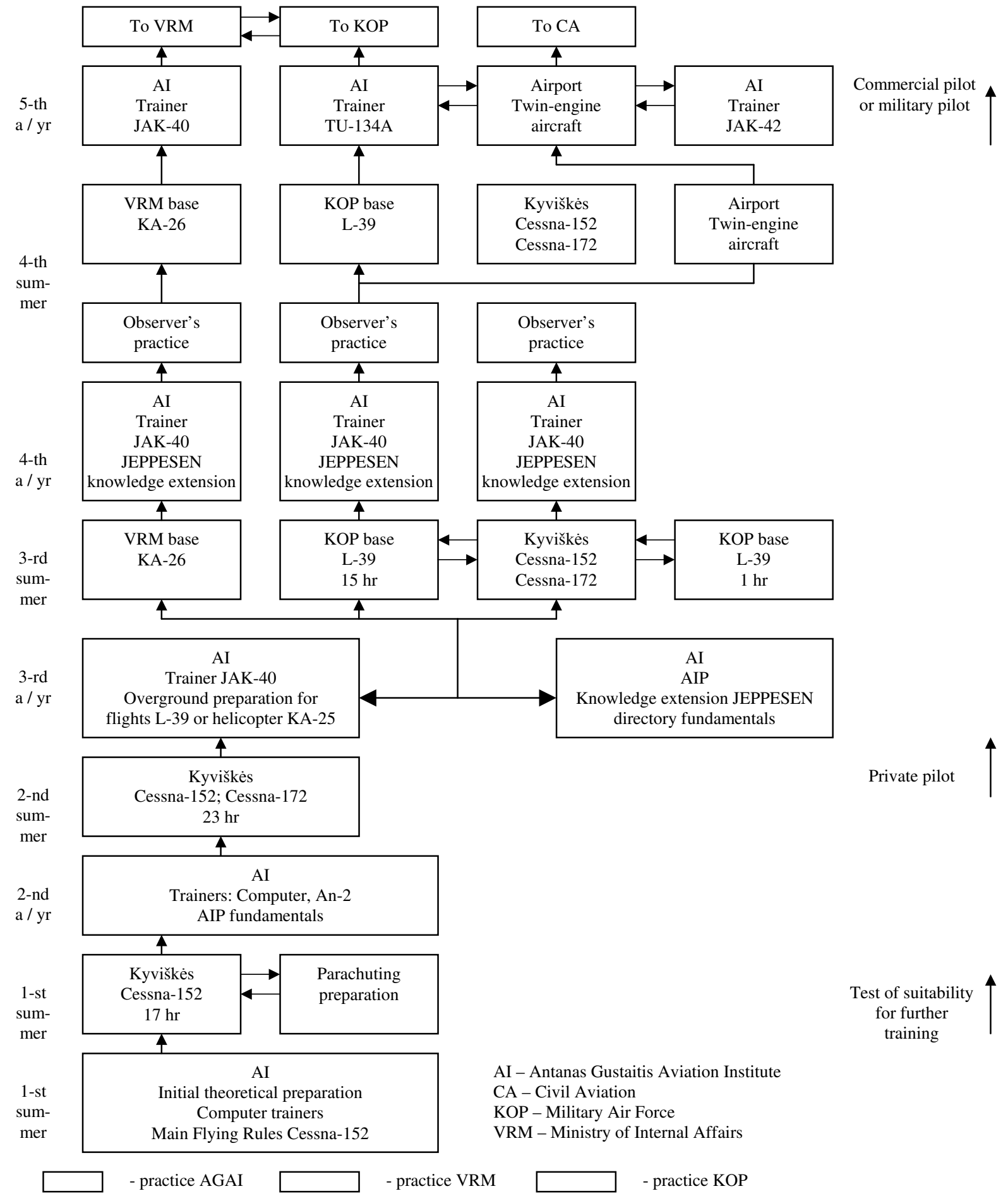

Fig 5. Structure of VGTU Antanas Gustaitis Aviation Institute programme for preparation of flying practice

In the second year of studies, Antanas Gustaitis Aviation Institute students are trained at the airport tower trainer and with trainer aircraft and computer trainers. In the second summer, practices of tower flight control officer and of short flying were carried out.

In the third year of studies, students were trained in the computer trainer as flying control officers for practice of flying control of approaches without and with radar to be carried out in the third summer.

In the fourth year of studies, exercises are done with the trainers at the Antanas Gustaitis Aviation Institute, and students are prepared for air space control without and with radar, which is carried out in the fourth summer and might be continued in the fifth year of studies.

Flight control summer practice is carried out at the Vilnius Air and Navigation Service (Stankūnas et al. 1999). 
Table 3. VGTU AGAI entrant and graduate dynamics (1993-2005)

\begin{tabular}{|c|c|c|c|c|c|c|c|c|c|c|c|c|c|}
\hline Year & & 93/94 & $94 / 95$ & 95/96 & 96/97 & $\begin{array}{l}97 / 98 \\
\end{array}$ & $98 / 99$ & 99/00 & $00 / 01$ & $1 / 2$ & $02 / 03$ & $3 / 4$ & $04 / 05$ \\
\hline & Entered & 61 & 126 & 97 & 109 & 144 & 159 & 168 & 131 & 118 & 130 & 130 & 108 \\
\hline & Bachelor & 61 & 98 & 82 & 89 & 88 & 84 & 97 & 70 & 71 & 89 & 87 & 75 \\
\hline $\begin{array}{l}\text { Aircraft } \\
\text { piloting }\end{array}$ & $\mathrm{OP}$ & 43 & 37 & 35 & 35 & 15 & 15 & 16 & & 16 & 17 & 14 & 15 \\
\hline $\begin{array}{l}\text { Flight } \\
\text { control }\end{array}$ & SV & & & & & 16 & 15 & 16 & 14 & 11 & & 13 & 9 \\
\hline $\begin{array}{l}\text { Flight } \\
\text { control }\end{array}$ & SKV & 18 & 34 & 23 & 26 & & & & & & & & \\
\hline $\begin{array}{l}\begin{array}{l}\text { Aviation } \\
\text { mechanics }\end{array} \\
\end{array}$ & SAV & & 27 & 24 & 28 & & & & & & & & \\
\hline $\begin{array}{l}\text { Aviation } \\
\text { mechanics }\end{array}$ & $\mathrm{AM}$ & & & & & 25 & 27 & 31 & 30 & 20 & 32 & 35 & 30 \\
\hline Automatics & $\mathrm{AU}$ & & & & & 15 & 13 & 17 & 14 & 11 & 19 & 12 & 15 \\
\hline \multirow{2}{*}{ Electronics } & $\mathrm{AE}$ & & & & & 17 & 14 & 17 & 12 & 13 & 21 & 13 & 6 \\
\hline & $\begin{array}{l}\begin{array}{l}\text { Special } \\
\text { profes- } \\
\text { sional }\end{array} \\
\end{array}$ & 0 & 28 & 15 & 20 & 35 & 44 & 40 & 46 & 25 & 22 & 23 & 17 \\
\hline $\begin{array}{l}\text { Aviation } \\
\text { mechanics }\end{array}$ & ORVi & & 14 & 10 & 4 & & & & & & & & \\
\hline $\begin{array}{l}\text { Air carrier } \\
\text { management }\end{array}$ & OVVi & & 14 & 5 & 11 & & & & & & & & \\
\hline $\begin{array}{l}\text { Aviation } \\
\text { electronics }\end{array}$ & AEi & & & & 5 & & 4 & & 17 & & & & \\
\hline $\begin{array}{l}\text { Aviation } \\
\text { electric } \\
\text { equipment }\end{array}$ & $\mathrm{AUi}$ & & & & & & & 10 & & & & & \\
\hline $\begin{array}{l}\text { Aircraft } \\
\text { piloting }\end{array}$ & $\mathrm{OPi}$ & & & & & 24 & 20 & 19 & 15 & 14 & 11 & 12 & 12 \\
\hline \multirow[t]{2}{*}{$\begin{array}{l}\text { Flight } \\
\text { control }\end{array}$} & $\mathrm{AVi}$ & & & & & 11 & 20 & 11 & 14 & 11 & 11 & 11 & 5 \\
\hline & Master & 0 & 0 & 0 & 0 & 21 & 31 & 31 & 15 & 22 & 19 & 20 & 16 \\
\hline $\begin{array}{l}\text { Air carrier } \\
\text { management }\end{array}$ & OVVm & & & & & 18 & 21 & 23 & & & & & \\
\hline $\begin{array}{l}\text { Aviation } \\
\text { mechanics }\end{array}$ & $\mathrm{AM} \mathrm{m}$ & & & & & 3 & 10 & 8 & 15 & 10 & 9 & 8 & 7 \\
\hline \multirow[t]{5}{*}{$\begin{array}{l}\text { Aviation } \\
\text { electronics }\end{array}$} & $\mathrm{AE} \mathrm{m}$ & & & & & & & & & 12 & 10 & 12 & 9 \\
\hline & $\begin{array}{l}\text { GRADU- } \\
\text { ATED }\end{array}$ & & & & & & & & & & & & \\
\hline & Total & & 25 & 13 & 57 & 90 & 88 & 114 & 108 & 92 & 83 & 65 & 60 \\
\hline & Bachelor & 0 & 0 & 0 & 40 & 56 & 38 & 53 & 49 & 54 & 51 & 37 & 38 \\
\hline & $\begin{array}{l}\% \text { of } \\
\text { entrants }\end{array}$ & & & & $66 \%$ & $57 \%$ & $46 \%$ & $60 \%$ & $56 \%$ & $64 \%$ & $53 \%$ & $53 \%$ & $54 \%$ \\
\hline $\begin{array}{l}\begin{array}{l}\text { Aircraft } \\
\text { piloting }\end{array} \\
\end{array}$ & OP & & & & 28 & 23 & 20 & 18 & 14 & 15 & 16 & 5 & 12 \\
\hline $\begin{array}{l}\text { Flight } \\
\text { control }\end{array}$ & SV & & & & & & & & 12 & 10 & 14 & 8 & 4 \\
\hline $\begin{array}{l}\begin{array}{l}\text { Flight } \\
\text { control }\end{array} \\
\end{array}$ & SKV & & & & 12 & 23 & 11 & 15 & & & & & \\
\hline $\begin{array}{l}\text { Aviation } \\
\text { mechanics }\end{array}$ & SAV & & & & & 10 & 7 & 20 & & & & & \\
\hline $\begin{array}{l}\text { Aviation } \\
\text { mechanics }\end{array}$ & AM & & & & & & & & 12 & 18 & 11 & 11 & 13 \\
\hline Automatics & $\mathrm{AU}$ & & & & & & & & 6 & 5 & 6 & 8 & 7 \\
\hline \multirow[t]{4}{*}{ Electronics } & $\mathrm{AE}$ & & & & & & & & 5 & 6 & 4 & 5 & 2 \\
\hline & $\begin{array}{l}\text { Special } \\
\text { profes- } \\
\text { sional }\end{array}$ & o & 25 & 13 & 17 & 34 & 34 & 37 & 31 & 25 & 16 & 18 & 13 \\
\hline & $\begin{array}{l}\% \text { of } \\
\text { entrants }\end{array}$ & & $89 \%$ & $87 \%$ & $85 \%$ & $97 \%$ & $77 \%$ & $93 \%$ & $67 \%$ & $100 \%$ & $73 \%$ & $78 \%$ & $76 \%$ \\
\hline & ORVi & & 12 & 8 & 4 & & & & & & & & \\
\hline $\begin{array}{l}\text { Air carrier } \\
\text { management }\end{array}$ & OVVi & & 13 & 5 & 11 & & & & & & & & \\
\hline $\begin{array}{l}\text { Aviation } \\
\text { electronics }\end{array}$ & $\mathrm{AEi}$ & & & & 2 & & 2 & & 5 & & & & \\
\hline $\begin{array}{l}\text { Aviation } \\
\text { electric } \\
\text { equipment }\end{array}$ & AUi & & & & & & & 6 & & & & & \\
\hline $\begin{array}{l}\text { Aircraft } \\
\text { piloting }\end{array}$ & OPi & & & & & 24 & 14 & 20 & 12 & 15 & 8 & 9 & 9 \\
\hline \multirow[t]{3}{*}{$\begin{array}{l}\text { Flight } \\
\text { control }\end{array}$} & SVi & & & & & 10 & 18 & 11 & 14 & 10 & 8 & 9 & 4 \\
\hline & Master & $\mathbf{0}$ & 0 & 0 & 0 & 0 & 16 & 24 & 28 & 13 & 16 & 10 & 9 \\
\hline & $\begin{array}{l}\% \text { of } \\
\text { entrants }\end{array}$ & & & & & & $76 \%$ & $77 \%$ & $90 \%$ & $87 \%$ & $73 \%$ & $53 \%$ & $45 \%$ \\
\hline $\begin{array}{l}\text { Air carrier } \\
\text { management }\end{array}$ & OVVm & & & & & & 15 & 15 & 22 & & & & \\
\hline $\begin{array}{l}\text { Aviation } \\
\text { mechanics }\end{array}$ & AMm & & & & & & 1 & 9 & 6 & 13 & 9 & 9 & 2 \\
\hline $\begin{array}{l}\text { Aviation } \\
\text { electronics }\end{array}$ & AEm & & & & & & & & & & 7 & 1 & 1 \\
\hline $\begin{array}{l}\text { Aviation } \\
\text { electric } \\
\text { equipment }\end{array}$ & AEIm & & & & & & & & & & & & 6 \\
\hline
\end{tabular}

\section{Formation of the three-level system for preparation of aviators}

Lithuanian aviation has become part of the European Union and global aviation system. Antanas Gustaitis
Aviation Institute is recognized as a higher educational institution meeting international requirements and the only aviation university in the Baltic States having all aviation studies programmes. It considerably excels other analogous aviation institutions in the neighbouring states, where most often only one or two certified study 
programmes exist. In 2005-2008, the institute received accreditation certificates confirming that it satisfies the European aviation administration standard requirements and may train private pilots, commercial aviation pilots, airline pilots, pilot instructors, flight control, and other aviation specialists and teach radio communication phraseology since the study programmes of the institute are in compliance with international standards. By other documents, it was recognized that AGAI study programmes are in conformity not only with international university requirements, but also international Chicago Convention International Civil Aviation Organization (ICAO) standards (Stankūnas et al. 2000).

By 2009 AGAI had trained a total of more than 1000 aviation specialists for civil and military aviation and other aviation enterprises. Almost the same number of specialists improved their qualifications at the institute. A three-level system for the training of aviation specialists was formed in Lithuania:

1. Private aviation specialist qualification level. This is the training of specialists in aviation clubs and aviation schools: glider pilots, parachutists, aero modellers, aviation technicians, light aircraft pilots and other specialists, and private pilots.

2. Professional aviation specialists with a higher qualification level.

3. Qualification improvement system for secondlevel aviators - courses, organized at AGAI and in the aviation organizations.

The Lithuanian Aeronautics Technology Platform, developed by AGAI and other institutions of education and science on January 18, 2006, should especially impart purposefulness to the studies and scientific research work. Here ways are foreseen to solve further issues relating to the training of aviators, strengthening of aviation bases, etc.

VGTU AGAI is valued in the world as one of most modern institutions in East Europe for the training of aviators of the highest qualification. In Lithuania, the institute has also become an integral part of the higher education system. The government of the Republic of Lithuania, with its Resolution No. 159 of 13 February 2008, approved "The 2008-2013 Programme for the Training of Aviation Specialists and Training Base Renovation". It is stated in the resolution that VGTU AGAI has been successful in the training of specialists in aircraft piloting, flight control, aviation mechanics, avionics, and aviation electric equipment. Additionally, the institute is in possession of accreditation certificates for the training of flight leaders, aircraft pilots, and aviation technical maintenance specialists and for the development of their qualifications. Since 1995, the institute's study programmes have been published in the register of study programmes of the International Civil Aviation Organization.

The resolution appreciates the participation of the institute's staff in international activities, representation at the European Union's $7^{\text {th }}$ Framework Programme Committee "Transport" (including Aeronautics), the European Union's Aeronautics Technology Platform ACARE, etc. The institute's scientific journal Aviation, collections of works by young scientists Aviation
Technologies, and international and national conferences have attained world renown.

However, many potentially successful activities of the institute are impeded by the lack of money, especially for the practical training of aircraft piloting and flight control students, quite outdated training facilities, an insufficient fleet of training airplanes, outmoded navigation equipment, improper equipping of training premises and specialized training laboratories, etc.

The resolution, taking into account the present situation, also foresees the solution of the following issues that are of special importance to the institute: the improvement of the quality of practical training for students, the founding of a new base for practical training flights, the renovation of training equipment necessary for aviation specialists, etc. The implementation measures of the programme approved by the government also foresee annual allocations from the state budget, thus enabling the institute to solve the issues relating to the training of highest qualification specialists and urgent tasks in the science of aeronautics.

The VGTU AGAI of today is listed among the best institutions in Eastern Europe for the training of the highest qualification aviation specialists. It has become an integral part of the Lithuanian higher education system.

\section{Conclusions}

In 1990, after the re-establishment of independence in Lithuania, with the efforts of VGTU scientists and other aviation enthusiasts, the Aviation Institute (Antanas Gustaitis Aviation Institute) was founded, and it fully justified hopes. The institute became the most important centre in Lithuania and Eastern Europe for the training of the highest quality aviators and gained popularity in the European Union and throughout the world.

The training of aviation specialists is not only one of the high-priced studies, but also to a great extent predetermines the progress of science and technology in the entire nation.

A promising future for Lithuanian aviation can be predicted not only due to the good systems for the preparation of specialists, but also due to the comparatively dense network of airports, a favourable geographic position, and the abundance of international airlines flying over Lithuania. However, the most important thing is that for many a Lithuanian aviation is linked to love and pride for the homeland. It is as if the fulfilment of the mandates inscribed in the will of Darius and Girènas, which was made in July 1933 before the historic flight of the Lituanica across the Atlantic from New York towards Kaunas: "The Lithuanian nation is awaiting for some more courageous deeds from its sons... Let the achievement of the Lituanica strengthen the spirit of young Lithuanian sons and inspire them to new deeds...". Darius and Girenas successfully crossed the Atlantic, achieving the fourth best result in the world considering the time and distance of the flight with a single-engine aircraft, but perished near Soldin, several hundred kilometres away from Kaunas. However, they 
will be alive in the hearts of Lithuanians forever and have become a symbol of service and self-sacrifice for the sake of Lithuania, a source of inspiration and endurance for "winged" Lithuanians.

\section{References}

Liekis, A. 2002. Lietuviu karyba ir ginkluote. V. $320-323$

Liekis, A. 2007. Lietuviu tautos prisikèlimas. V. $530-533$.

Liekis, A. 1999. Lietuvos karo aviacija (1919-1940 m.). V. $20-28$.

Liekis, A. 2008. Sparnuotoji Lietuva. V. 320 p.

Stankūnas, J. 1998. Aviacijos specialistai: situacija ir prognozè. Aviacija. Mokslo darbai. Vilnius: Technika. (3): 173 - 178. ISSN 1392-6276.

Stankūnas, J. 2000. Integrated system for training of aviation specialists: concept and experience. Research Bulletin: Proceedings of the Fourth Seminar "Recent Research and Design Progress in aeronautical Engineering and its Influence on Education", part 1. Warsaw University of Technology, 10: 191-198.

Stankūnas, J. 1999. Internal and international cooperation as a precondition for the organization of aviation studies: concept and experience. In Proc. of First Regional TRAINAIR Co-ordination Conference, Amman, Jordan. 8.

Stankūnas, J. 1999. Lietuvos aviacija: tradicijos, pasiekimai, integravimasis i tarptautines aviacijos sistemas. Iš Technikos žodis. Amerikos lietuviu inžinieriu ir architektu sajungos ALIAS organas. Čikaga. (3): 8-11.

Stankūnas, J. 1995. Lietuvos integracija i pasaulinę aviacijos specialistų rengimo sistemą. Iš Lietuvos mokslas. IV kn., 10: 75-81.

Stankūnas, J. 1999. Training of pilots for Lithuanian Air Force: Concept and experience. In Meeting of NATO Air force Armaments Group (NATO) Headquarters, Brussels, Belgium. 9.

Stankūnas, J.; Balandis, D. 2000. Lietuvos civilinès aviacijos integracija i tarptautines post sovietines struktūras. Iš Transporto problemos ir ju sprendimo būdai. Lietuvos mokslu akademijos sekcijos pranešimu medžiaga. Vilnius: Technika. 69-95.

Stankūnas, J.; Balandis, D. 1999. Lietuvos civilinès aviacijos pasirengimas veiklai Europos aviacijos bendrijoje zonoje. Aviacija. Vilnius: Technika. (4): 121-126.

Stankūnas, J.; Balandis, D. 2000. The problems of integration into international and European civil aviation structures. Aviacija. Vilnius: Technika. (5): 13-17. ISSN 1392-1533.

Stankūnas, J.; Balandis, D.; Kaminskas, V. 1998. Lietuvos civilinès aviacijos integravimasis $\mathfrak{i}$ tarptautinę sistemą: teisinès problemos. Aviacija. Vilnius: Technika. (3): 128-131. ISSN 1392-6276.

Stankūnas, J.; Giniotis, V. 2000. Analysis of shortrange measurements in the space. Aviacija. Vilnius: Technika. (5): 101-104. ISSN 13921533.

Stankūnas, J.; Lasauskas, E.; Leonavičius, K. ir kt. 2002. Lightweight aircraft structures in Lithuania: research, desighn and manufacture. In Materials of UAV-NET Meeting 2 at CIRA in Capua. Italy [online], 15-20. Available from Internet: < www.UAVNET.COM>.

\section{Abbreviations}

VISI - Vilnius Civil Engineering Institute VTU - Vilnius Technical University VGTU - Vilnius Gediminas Technical University ICAO - International Civil Aviation Organization ECAS - European Civil Aviation Conference IATA - International Air Transport Association

\title{
AUKŠČIAUSIOS KVALIFIKACIJOS AVIACIJOS SPECIALISTŲ RENGIMAS NEPRIKLAUSOMOJE LIETUVOJE (1990 - 2009 m.)
}

\begin{abstract}
A. Liekis
S a n tra k a

Dar tarpukario nepriklausomoje Lietuvoje rengti planai įsteigti Lietuvoje aukštają aeronautikos mokyklą. Bet tik 1990 m. Lietuvai atkūrus nepriklausomybę susidare galimybės tuos planus igyvendinti: tuometinio VTU prof. Jono Stankūno, rektoriaus prof. Edmundo Kazimiero Zavadsko pastangų dẻka, o taip pat remiant daugeliui Lietuvos aviatorių, Susisiekimo ministerijai ir kitu instituciju specialistams 1993 m. pradžioje VTU buvo ¡kurtas Aviacijos institutas, vėliau pavadintas žinomo aviakonstruktoriaus, buvusio Lietuvos Kariuomenės generolo Antano Gustaičio vardu. Straipsnyje pateikiama instituto įsteigimo istorija, suformuotų studijų ir praktikos programų ir kaip jos atitinka tarptautinį lygmenį analizė. Straipsnyje pateikta analizė pasitarnaus toliau tobulinant aukščiausios kvalifikacijos specialistų rengimą, sprendžiant aviacijos organizavimo ir valdymo klausimus.
\end{abstract}

